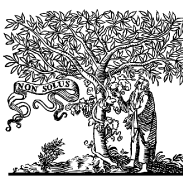

ELSEVIER MASSON
Elsevier Masson France

www.em-consulte.com/en

Review

\title{
Vitamin D and type 2 diabetes mellitus: Where do we stand?
}

\author{
E. Cavalier ${ }^{\mathrm{a}, *}$, P. Delanaye ${ }^{\mathrm{b}}$, J.-C. Souberbielle ${ }^{\mathrm{c}}$, R.-P. Radermecker ${ }^{\mathrm{d}}$ \\ ${ }^{a}$ Department of Clinical Chemistry, University of Liege, CHU Sart-Tilman, 4000 Liège, Belgium \\ ${ }^{\mathrm{b}}$ Department of Nephrology, Dialysis and Hypertension, University of Liege, CHU Sart-Tilman, 4000 Liège, Belgium \\ ${ }^{c}$ Laboratoire d'explorations fonctionnelles, hôpital Necker-Enfants-Malades, 75743 Paris, France \\ ${ }^{\mathrm{d}}$ Department of Diabetes, Nutrition and Metabolic Disorders, University of Liege, CHU Sart-Tilman, 4000 Liège, Belgium
}

Received 3 January 2011; received in revised form 5 January 2011; accepted 8 January 2011

\begin{abstract}
Aims. - In-vitro and observational studies have established a link between vitamin D deficiency and different type 2 diabetes outcomes (insulin resistance, insulin secretion, glucose intolerance). Although the number of randomized controlled trials vs placebo is small, vitamin D (VTD) has been shown to prevent increases in glucose concentration and insulin resistance, enhance insulin sensitivity and reduce systolic blood pressure in type 2 diabetic patients.

Methods. - In this review, we have focused on the potential mechanisms that might explain the association between VTD and type 2 diabetes mellitus (T2DM). We have also evaluated the different epidemiological and observational studies on the topic, as well as the various interventional studies.

Results. - Although the in vitro studies appear to be promising in explaining the link between VTD metabolism and T2DM, the results of in vivo studies are conflicting. This could be related to differences in their methodological approaches.

Conclusion. - Although more studies are needed to confirm the role of VTD in the treatment of T2DM, there is nevertheless enough evidence at this time to suggest a need to maintain $25-\mathrm{OH}$ vitamin D levels in T2DM patients around $30 \mathrm{ng} / \mathrm{mL}$ over the course of a year.

(C) 2011 Elsevier Masson SAS. All rights reserved.
\end{abstract}

Keywords: Vitamin D; Type 2 diabetes mellitus; Pathophysiology; Review

\section{Résumé}

Vitamine D et diabète de type 2: le point en 2011.

Introduction. - Des études, tant observationnelles qu'in vitro ont établi l'existence d'un lien entre une carence en vitamine D et différentes complications liées au diabète de type 2 (résistance à l'insuline et intolérance au glucose). Le nombre d'études randomisées en double insu contre placebo est malheureusement assez limité, mais il n'empêche qu'il a déjà été démontré que la vitamine D permettait de diminuer les augmentations de la glycémie ainsi que la résistance à l'insuline, augmentait la sensibilité à l'insuline et réduisait la pression artérielle systolique chez le patient diabétique de type 2 .

Méthodes. - Dans ce travail, nous nous sommes intéressés aux mécanismes pouvant expliquer l'association vitamine D-diabète de type 2. Nous avons également étudié quelques grandes études observationnelles et épidémiologiques et nous nous sommes concentrés sur les études randomisées en double insu contre placebo publiées à ce jour.

Résultats. - Les études in vitro semblent assez prometteuses, mais les résultats observés dans les études in vivo sont assez conflictuels, souvent à cause de différences de méthodologies.

Conclusion. - Nous avons encore besoin d'autres études pour clarifier le rôle de la vitamine D dans le traitement du patient diabétique de type 2, mais il semble cependant évident que les concentrations plasmatiques en 25(OH)-vitamine D de ces patients devraient être maintenues aux environs de $30 \mathrm{ng} / \mathrm{mL}$ tout le long de l'année.

(C) 2011 Elsevier Masson SAS. Tous droits réservés.

Mots clés : Vitamine D ; Diabète de type 2; Physiopathologie ; Revue générale

\section{Introduction}

* Corresponding author. Tel.: +32436676 92; fax: +32 43667691 .

E-mail address: Etienne.cavalier@chu.ulg.ac.be (E. Cavalier).
Vitamin D (VTD) is, in fact, not a vitamin, but a prohormone. Indeed, only a small amount of VTD can be obtained from the

1262-3636/\$ - see front matter (C) 2011 Elsevier Masson SAS. All rights reserved. doi: $10.1016 /$ j.diabet.2011.01.001 
Table 1

Foods that naturally contain vitamin D.

\begin{tabular}{ll}
\hline Food & Content (IU/100 g) \\
\hline Halibut liver oil (D3) & 200,000 \\
Cod liver (D3) & 8500 \\
Sea eel (D3) & 520 \\
Smoked river eel (D3) & 3600 \\
Cod (D3) & 50 \\
Halibut (D3) & 200 \\
Black halibut (D3) & 600 \\
Herring (D3) & 1250 \\
Sea bass (D3) & 20 \\
Mackerel (D3) & 40 \\
Sardine (D3) & 300 \\
Salmon (D3) & 650 \\
Canned salmon (D3) & 450 \\
Redfish (D3) & 90 \\
Sole (D3) & 60 \\
Tuna (D3) & 200 \\
Oyster (D3) & 300 \\
Butter (D3) & 50 \\
Margarine (D3) & 300 \\
Crème fraîche (D3) & 40 \\
Calf's liver (D3) & 130 \\
Poultry liver (D3) & 50 \\
Milk (D3) & 1 \\
Cheese (D3) & $10-20$ \\
Egg (D2 and D3) & 70 \\
Liquid yolk (D2 and D3) & 220 \\
\hline
\end{tabular}

diet, as it is naturally present in very few foods (Table 1). Thus, the main source of vitamin D is sunlight-induced photochemical conversion of 7-dehydrocholesterol after exposure of the skin to ultraviolet B (UVB) rays (wavelength: $270-300 \mathrm{~nm}$ ). VTD is found in two forms: the first, vitamin D3 (cholecalciferol), is the molecule synthesized in the skin, and is also present in some foods (mainly fatty fish from cold waters); the second, vitamin D2 (ergocalciferol), is the vitamin D found in plants (Fig. 1).

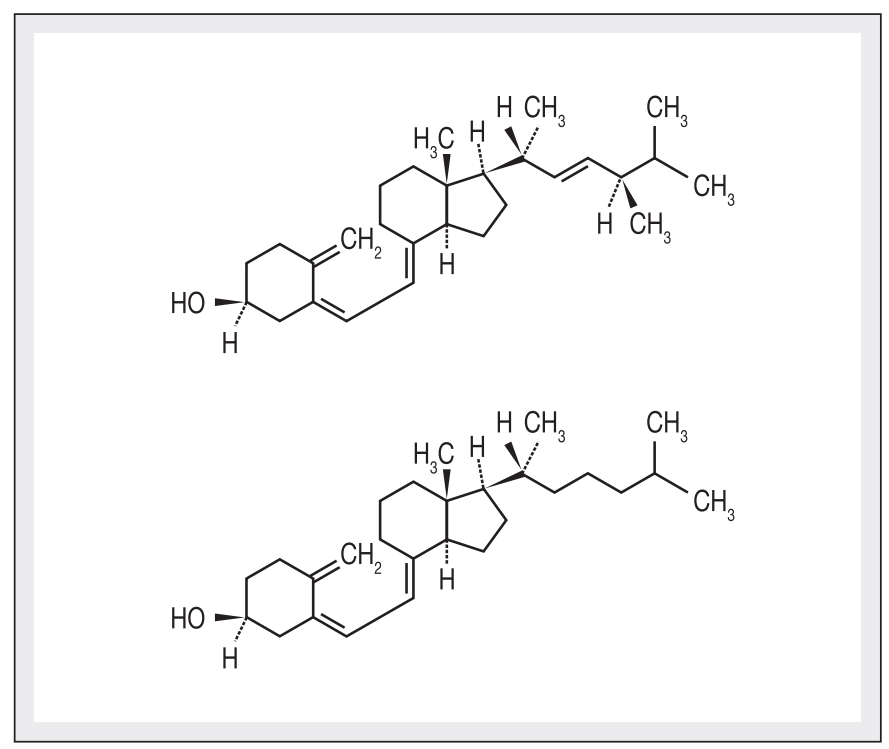

Fig. 1. Molecular structures of (upper) vitamin D2 (ergocalciferol) and (lower) vitamin D3 (cholecalciferol).
Either vitamin D2 or D3 can also be found in many pharmacological supplements but, whatever the source of the vitamin, it circulates in the bloodstream bound to a carrier protein, the vitamin D binding protein (DBP). In addition, VTD must be hydroxylated twice to produce the most biologically active form-1,25(OH)2 vitamin D. The first step of hydroxylation, on the carbon in position 25, takes place in the liver to form 25 hydroxyvitamin D (25OHD). This step is poorly regulated: the more vitamin D synthesized or ingested, the greater the quantity of $25 \mathrm{OHD}$ formed, although some studies have shown a negative correlation between the increase in 25OHD and baseline plasma concentration. The half-life of 25OHD is approximately 3-4 weeks. The 25OHD-DBP complex enters the proximal renal tubule, where the second step of hydroxylation occurs on the carbon in position 1 by the enzyme 1-alpha-hydroxylase (CYP27B1), resulting in 1,25(OH)2 vitamin D (calcitriol). This renal stage of hydroxylation is tightly regulated, and mainly stimulated by parathormone (PTH), hypophosphataemia and poor calcium intakes. The enzyme is down-regulated by fibroblast growth factor-23 (FGF-23), hyperphosphataemia and $1,25(\mathrm{OH}) 2$ vitamin D itself. The half-life of $1,25(\mathrm{OH}) 2$ vitamin $\mathrm{D}$ is approximately $4 \mathrm{~h}$.

The best-known role of $1,25(\mathrm{OH}) 2$ vitamin $\mathrm{D}$ is to maintain phosphocalcic homoeostasis by enhancing calcium and phosphorus uptake in the gut. This endocrine function is achieved by acting on a cytosolic receptor (the vitamin D receptor, or VDR), thus inducing the synthesis of different proteins, such as TRPV6, calbindin 9 and NPT2b. Severe VTD deficiency can cause rickets in children and osteomalacia in adults.

In addition to this endocrine function, VTD plays an important autocrine role. Indeed, most human cells express VDRs and possess 1-alpha-hydroxylase. The 25OHD penetrates these cells and is hydroxylated to produce $1,25(\mathrm{OH}) 2$ vitamin $\mathrm{D}$, which remains localized to the cells and binds to the VDR. The 1,25(OH)2 vitamin D-VDR complex penetrates into the nucleus of the cells and is combined with the retinoic-acid receptor (RXR). The RXR-VDR-1,25(OH)2 vitamin D complex acts on various 'vitamin $\mathrm{D}$ responsive elements' (VDRE) that are close to the genes whose expression is thus activated or depressed, thereby modulating the synthesis of numerous proteins [1].

It is now believed that up to $3 \%$ of the human genome is directly or indirectly controlled by the VTD system [2]. In addition, more and more observational, experimental and also interventional studies have recently emerged to demonstrate the contribution of significant VTD supplementation to different health benefits. Of these so far, it is worth noting its positive effects on cancer [3], sarcopenia in the elderly [4], multiple sclerosis [5], hypertension [6], cardiovascular disease [7], congestive heart failure [8], lupus erythematosus [9], arthritis [10], type 1 diabetes [11] and various infectious diseases [12].

Although there is, as yet, no consensus to recommend a target range for serum 25OHD concentrations, the present report supports the suggestion that vitamin $\mathrm{D}$ insufficiency is defined by $25 \mathrm{OHD}$ levels less than $30 \mathrm{ng} / \mathrm{mL}(75 \mathrm{nmol} / \mathrm{L})$, 
as has already been proposed by several teams of experts [13-16].

\section{Association of vitamin $D$ and type 2 diabetes mellitus: in vitro and animal studies}

Many different basic and animal studies have shown that VTD and calcium $(\mathrm{Ca})$ are clearly involved in glycaemic homoeostasis, and that altered $\mathrm{Ca}$ and VTD concentrations play a role in the development of diabetes. The relationship between vitamin $\mathrm{D}$, $\mathrm{Ca}$ and insulin was elucidated in 1967, when Milner and Hales [17] showed that, in animals, Ca and magnesium (tightly regulated by the VTD system) were essential for insulin secretion. Also, having an inadequate VTD status may play a role in insulin resistance [18-21]: indeed, VTD has a direct effect on insulin action, as it stimulates the expression of the insulin receptor and, thus, enhances responsiveness for glucose transport [22]. Vitamin D also has indirect (Ca-mediated) effects on insulin action: $\mathrm{Ca}$ is tightly regulated, and intracellular $\mathrm{Ca}^{2+}$ concentrations must be kept within an extremely narrow range for the optimal action of insulin on different insulin-responsive tissues, such as skeletal muscle and fat tissue [23-25]. Changes in intracellular $\mathrm{Ca}^{2+}$ concentrations can lead to peripheral insulin resistance via impaired insulin signal transduction, with decreased glucose transporter-4 (GLUT4) activity [26]. Vitamin D also plays an active role in the functional regulation of the endocrine pancreas, as beta cells possess both VTD receptors [27] and 1-alphahydroxylase [28]. Furthermore, calbindin-D28k, a Ca-binding protein regulated by the VTD pathway, plays a role in the modulation of depolarization-stimulated insulin release (and, thus, controls the rate of insulin release via regulation of intracellular $\mathrm{Ca}^{2+}$ concentration) [29], and also protects beta cells against cytokine-mediated apoptosis and necrosis by inhibiting free radical formation [30]. Finally, different polymorphisms of the VDR have also been associated with T2DM, the metabolic syndrome, fasting plasma glucose and glucose intolerance [31-33].

\section{Vitamin D and type 2 diabetes mellitus: epidemiology and observational studies}

In 2009, the World Health Organization (WHO) estimated that 220 million people worldwide had diabetes. Vitamin D deficiency is another global problem, as it has been estimated that more than one billion people worldwide are vitamin D-deficient [1].

Seasonal variations of preprandial glucose, HbAlc concentration and glycaemic control have been demonstrated in T2DM patients, being higher in winter and lower in summer [34,35]. As winter is the season when sunshine (and vitamin D production) is reduced (with no skin vitamin D production in northern regions), these observations could be suggesting that these seasonal variations are linked to seasonal variations of vitamin D.

A cross-sectional survey of 5677 individuals in New Zealand concluded that serum concentrations of $25 \mathrm{OHD}$ were altered in patients with newly diagnosed T2DM and impaired glucose tolerance. The study also showed ethnic differences in vitamin
D among participants (with Maori and Pacific Islanders having lower levels than Europeans) [36].

Also, the Third National Health and Nutrition Examination Survey (NHANES III) [37] showed an inverse association between vitamin $\mathrm{D}$ status and diabetes in non-Hispanic whites and Mexican-Americans, but not in non-Hispanic blacks, again reflecting ethnic differences. [AU: please check ref numbers here; note ref 38 citation is missing in sequence. SW, editor] Pittas et al. [39] found statistically significant inverse associations between $25 \mathrm{OHD}$ concentrations and the prevalence of T2DM (odds ratio: $0.36,95 \%$ CI: $0.16-0.80$ ) on analyzing data from all studies reporting an association between 25OHD and diabetes prevalence, excluding data for non-Hispanic blacks $[36,50,51]$. Other cross-sectional or observational studies have been published on the topic, and their results generally-but not always-suggest an association between VTD status and/or Ca intake and T2DM risk. However, it is not reasonable to rely on these studies for a number of reasons, including: (1) lack of being adjusted for confounding factors (for example, body mass index, VTD and Ca status, physical activity and outdoor activity); (2) major differences in the populations studied (ethnicity, mean age, geographical location/latitude); and (3) wide range of pathologies present and different outcomes (such as newly diagnosed diabetics, glucose tolerance problems and insulin resistance).

Nevertheless, in the Nurses' Health Study, it appears that women with the highest intakes of $\mathrm{Ca}$ (greater than $1200 \mathrm{mg} /$ day) and VTD (greater than 800 IU/day) had a 33\% lower risk compared with those who had the lowest Ca (less than $600 \mathrm{mg} /$ day) and VTD (less than 400 IU/day) intakes. It is also worth noting that, in that study, the combination of Ca and VTD appeared to be more effective than either high-dose Ca or VTD supplements alone [38].

Finally, it should be borne in mind that, while some studies have shown either a positive or no effect of VTD, no negative study of the topic has ever been published.

\section{Vitamin D and type 2 diabetes mellitus: interventional studies}

In evidence-based medicine, the level of evidence from interventional studies is much more important than that of observational or cross-sectional studies. In researching the use of significant VTD supplementation to achieve potential benefits in T2DM, different interventional studies have been conducted. However, these studies have major differences in design and outcomes. For this reason, the present report focuses only on those studies where 25OHD levels were determined. Indeed, it is difficult to draw any conclusions from studies where the most important determining factor was not evaluated. Also, only those studies where 'native' vitamin D3 or D2 was given to patients are included. In fact, it is not usually considered good practice to supplement patients with 1-hydroxylated or 1.25-dihydroxylated VTD as the first line of treatment.

Given these criteria, only one study of all those systematically and well reviewed, and including meta-analysis, by Pittas et al. on the role of vitamin D and Ca in T2DM (published in 2007) 
Table 2

Randomized controlled trials of the effect of vitamin D (VTD) and/or calcium (Ca) supplementation in type 2 diabetic (T2DM) patients.

\begin{tabular}{|c|c|c|c|c|c|c|c|c|}
\hline $\begin{array}{c}\text { First author, } \\
\text { year [ref], } \\
\text { location }\end{array}$ & Gender & $\begin{array}{l}\text { Age (years, } \\
\text { mean or range) }\end{array}$ & $\begin{array}{l}\text { Study } \\
\text { participants }\end{array}$ & $\begin{array}{l}25 \mathrm{OHD} \text { conc } \\
\text { and } \mathrm{Ca} \text { intake } \\
\text { at baseline }\end{array}$ & $\begin{array}{l}25 \mathrm{OHD} \text { conc } \\
\text { at study end; } \\
\text { VTD assay }\end{array}$ & $\begin{array}{l}\text { Interventional } \\
\text { modalities }\end{array}$ & Main outcome & $\begin{array}{l}\text { Comments and } \\
\text { outcomes }\end{array}$ \\
\hline $\begin{array}{l}\text { Pittas, } 2007 \\
\text { [40], New } \\
\text { England, } \\
\text { USA }\end{array}$ & $\mathrm{M} / \mathrm{F}$ & 71 & $\begin{array}{l}\text { Normal fasting } \\
\text { glucose, } \\
n=222 ; \\
\text { impaired } \\
\text { fasting } \\
\text { glucose, } n=92 \text {; } \\
\text { non-diabetic, } \\
100 \% \text { white; } \\
\text { BMI: } \\
26.7 \mathrm{~kg} / \mathrm{m}^{2}\end{array}$ & $\begin{array}{l}30 \mathrm{ng} / \mathrm{mL} ; \mathrm{Ca}: \\
750 \mathrm{mg} / \text { day }\end{array}$ & $\begin{array}{l}40 \mathrm{ng} / \mathrm{mL} ; \\
\text { CPBA }\end{array}$ & $\begin{array}{l}\text { D3 } \\
700 \mathrm{IU} / \text { day + Ca } \\
\text { citrate } \\
500 \mathrm{mg} / \text { day vs } \\
\text { placebo;3-year } \\
\text { study }\end{array}$ & $\begin{array}{l}\text { Normal group } \\
\text { fasting } \\
\text { glucose: no } \\
\text { apparent } \\
\text { effect; } \\
\text { impaired } \\
\text { fasting glucose } \\
\text { group: no } \\
\text { increase in } \\
\text { plasma } \\
\text { glucose and no } \\
\text { insulin } \\
\text { resistance } \\
\text { (also seen in } \\
\text { placebo group) }\end{array}$ & $\begin{array}{l}\text { Somewhat higher } \\
25 \mathrm{OHD} \text { levels at } \\
\text { baseline in these older } \\
\text { patients }\end{array}$ \\
\hline $\begin{array}{l}\text { Avenell, } 2009 \\
\text { [42], } \\
\text { England and } \\
\text { Scotland }\end{array}$ & $\mathrm{M} / \mathrm{F}$ & 77 & $\begin{array}{l}\text { RECORD } \\
\text { trial: } 5292 \\
\text { participants } \\
\text { with recent } \\
\text { osteoporotic } \\
\text { fracture; } 99 \% \\
\text { white, } 8 \% \\
\text { diabetic; BMI: } \\
\text { not reported, } \\
\text { but mean } \\
\text { weight was } \\
65 \mathrm{~kg}, \text { so BMI } \\
\text { may have been } \\
\text { around } \\
26.7 \mathrm{~kg} / \mathrm{m}^{2}\end{array}$ & $\begin{array}{l}15.2 \mathrm{ng} / \mathrm{mL} \text { in } \\
60 \text { subjects; } \\
\mathrm{Ca}:<700 \mathrm{mg} / \text { day } \\
\text { in } 39 \%\end{array}$ & 24.8 ng/mL;HPL & $\begin{array}{l}\text { DD3 } \\
800 \text { IU/day, Ca } \\
\text { carbonate } \\
1000 \mathrm{mg} / \text { day, } \\
\text { both or } \\
\text { placebo; } \\
\text { follow-up: } \\
24-62 \text { months }\end{array}$ & $\begin{array}{l}\text { No prevention } \\
\text { of diabetes } \\
\text { development } \\
\text { or increase in } \\
\text { need for } \\
\text { diabetes } \\
\text { medication }\end{array}$ & $\begin{array}{l}\text { Doses too low to } \\
\text { achieve } 30 \mathrm{ng} / \mathrm{mL}\end{array}$ \\
\hline $\begin{array}{c}\text { Tai, } 2008 \text { [41], } \\
\text { Australia }\end{array}$ & $\mathrm{M} / \mathrm{F}$ & 55 & $\begin{array}{l}33 \text { VTD } \\
\text { insufficient } \\
(<20 \mathrm{ng} / \mathrm{mL}) \text {, } \\
\text { with or } \\
\text { without } \\
\text { secondary } \\
\text { hyperparathy- } \\
\text { roidism; no } \\
\text { history of } \\
\text { diabetes; BMI: } \\
24.1 \mathrm{~kg} / \mathrm{m}^{2} \text {; } \\
94 \% \text { white }\end{array}$ & $\begin{array}{l}16 \mathrm{ng} / \mathrm{mL} ; \mathrm{Ca}: \\
\text { those who } \\
\text { took } \\
\text { supplements } \\
\text { were allowed } \\
\text { to go on ( } 10 \\
\text { patients) }\end{array}$ & $\begin{array}{l}36 \mathrm{ng} / \mathrm{mL} ; \mathrm{IDS} \\
\text { RIA }\end{array}$ & $\begin{array}{l}\text { 75-g standard } \\
\text { OGTT; Then } \\
\text { 100,000 IU of } \\
\text { D3 + 100,000 IU } \\
2 \text { weeks later; } \\
2 \text { weeks after } \\
\text { second dose: } \\
\text { new OGTT }\end{array}$ & $\begin{array}{l}\text { In adults } \\
\text { without } \\
\text { diabetes, } \\
\text { correction of } \\
\text { VTD } \\
\text { deficiency not } \\
\text { associated } \\
\text { with any effect } \\
\text { on blood } \\
\text { glucose or } \\
\text { insulin } \\
\text { metabolism; } \\
\text { assessed by } \\
\text { OGTT }\end{array}$ & $\begin{array}{l}\text { Not a randomized } \\
\text { controlled trial }\end{array}$ \\
\hline $\begin{array}{l}\text { Sugden, } 2008 \\
\text { [43], } \\
\text { Scotland }\end{array}$ & $\mathrm{M} / \mathrm{F}$ & 64 & $\begin{array}{l}34 \text { patients } \\
\text { with T2DM; } \\
\text { VTD } \\
\text { insufficient } \\
\text { (<20 ng/mL); } \\
\text { ? } 100 \% \text { white } \\
\text { (not reported); } \\
\text { BMI: } \\
31.7 \mathrm{~kg} / \mathrm{m}^{2}\end{array}$ & $\begin{array}{l}16.1 \mathrm{ng} / \mathrm{mL} ; \\
\text { Ca: not } \\
\text { reported }\end{array}$ & $\begin{array}{l}25.3 \mathrm{ng} / \mathrm{mL} \\
\text { (mean increase } \\
\text { of } 6.1 \mathrm{ng} / \mathrm{mL} \\
\text { vs placebo); } \\
\text { IDS ELISA }\end{array}$ & $\begin{array}{l}\text { Measure of } \\
\text { endothelial } \\
\text { function by } \\
\text { flow-mediated } \\
\text { vasodilatation } \\
\text { of brachial } \\
\text { artery; then } \\
100,000 \mathrm{IU} \text { of } \\
\text { D2 or placebo; } \\
8 \text { weeks later: } \\
\text { re-evaluation } \\
\text { of endothelial } \\
\text { function }\end{array}$ & $\begin{array}{l}\text { Improvement } \\
\text { in brachial } \\
\text { artery flow in } \\
\text { VTD group by } \\
2.3 \% \text {, } \\
\text { significant } \\
\text { even after } \\
\text { adjusting for } \\
\text { blood } \\
\text { pressure; VTD } \\
\text { supplementa- } \\
\text { tion decreased } \\
\text { blood pressure } \\
\text { by } 14 \text { mmHg }\end{array}$ & $\begin{array}{l}\text { Of interest, as } \\
\text { endothelial function is } \\
\text { powerful surrogate } \\
\text { marker of } \\
\text { cardiovascular risk; } \\
\text { however, limited } \\
\text { number of patients; as } \\
\text { use of D2 reduces } \\
\text { blood levels of } \\
25 \text { OHD3, more } \\
\text { significant results are } \\
\text { to be expected with } \\
\text { D3 supplementation; } \\
30 \text { ng/mL not } \\
\text { achieved; very obese } \\
\text { patients }\end{array}$ \\
\hline
\end{tabular}


Table 2 (Continued)

\begin{tabular}{|c|c|c|c|c|c|c|c|c|}
\hline $\begin{array}{c}\text { First author, } \\
\text { year [ref], } \\
\text { location }\end{array}$ & Gender & $\begin{array}{l}\text { Age (years, } \\
\text { mean or range) }\end{array}$ & $\begin{array}{l}\text { Study } \\
\text { participants }\end{array}$ & $\begin{array}{l}25 \mathrm{OHD} \text { conc } \\
\text { and } \mathrm{Ca} \text { intake } \\
\text { at baseline }\end{array}$ & $\begin{array}{l}25 \mathrm{OHD} \text { conc } \\
\text { at study end; } \\
\text { VTD assay }\end{array}$ & $\begin{array}{l}\text { Interventional } \\
\text { modalities }\end{array}$ & Main outcome & $\begin{array}{l}\text { Comments and } \\
\text { outcomes }\end{array}$ \\
\hline $\begin{array}{l}\text { von Hurst, } \\
2010 \text { [47], } \\
\text { New } \\
\text { Zealand }\end{array}$ & $\mathrm{F}$ & $23-68$ & $\begin{array}{l}81 \text { insulin- } \\
\text { resistant } \\
\text { non-diabetic } \\
\text { South Asian } \\
\text { women living } \\
\text { in Auckland } \\
\text { (population at } \\
\text { high risk of } \\
\text { T2DM) with } \\
\text { VTD } \\
\text { insufficiency } \\
(<20 \mathrm{ng} / \mathrm{mL} \text { ); } \\
\text { BMI: } \\
27.5 \mathrm{~kg} / \mathrm{m}^{2}\end{array}$ & $\begin{array}{l}8.4 \mathrm{ng} / \mathrm{mL} ; \mathrm{Ca}: \\
\text { not reported }\end{array}$ & $\begin{array}{l}32 \mathrm{ng} / \mathrm{mL} \\
\text { (mean increase } \\
\text { of } 18.8 \mathrm{ng} / \mathrm{mL} \\
\text { vs placebo); } \\
\text { DiaSorin RIA }\end{array}$ & $\begin{array}{l}\text { Study of the } \\
\text { insulin } \\
\text { resistance } \\
\text { (assessed as } \\
\text { HOMA } 1 \text { and } \\
\text { HOMA } 2 \\
\text { models) after } \\
4000 \text { IU/day of } \\
\text { D3 or placebo } \\
\text { for } 6 \text { months }\end{array}$ & \multirow[t]{2}{*}{$\begin{array}{l}\text { Significant } \\
\text { improvements in } \\
\text { insulin sensitivity, } \\
\text { insulin resistance } \\
\text { and fasting insulin } \\
\text { decrease in VTD } \\
\text { group; insulin } \\
\text { resistance most } \\
\text { improved when } \\
25 \mathrm{OHD} \text { levels } \\
\text { were } \geq 32 \mathrm{ng} / \mathrm{mL}\end{array}$} & \multirow[t]{2}{*}{$\begin{array}{l}\text { Rare study where } \\
32 \mathrm{ng} / \mathrm{mL} \text { level was } \\
\text { achieved; obese } \\
\text { patients }\end{array}$} \\
\hline $\begin{array}{c}\text { Nagpal, } 2009 \\
\text { [45], India }\end{array}$ & M & $\begin{array}{l}>35(\text { mean } \\
\text { between } 42.4 \\
\text { and } 45.0)\end{array}$ & $\begin{array}{l}74 \text { obese } \\
\text { (waist } \\
\text { circumfer- } \\
\text { ence } \geq 78 \mathrm{~cm} \text { ) } \\
\text { non-diabetic } \\
\text { healthy Indian } \\
\text { men; } \mathrm{BMI} \text { : } \\
26.7 \mathrm{~kg} / \mathrm{m}^{2}\end{array}$ & $\begin{array}{l}14.6 \mathrm{ng} / \mathrm{mL} \text {; } \\
\mathrm{Ca}: \text { not } \\
\text { reported }\end{array}$ & $\begin{array}{l}28.6 \mathrm{ng} / \mathrm{mL} ; \\
\text { DiaSorin RIA }\end{array}$ & $\begin{array}{l}75 \text {-g OGTT; } \\
\text { Then, } \\
120,000 \text { IU of } \\
\text { D3 × } 3 \text { (total: } \\
460,000 \text { ) at } \\
\text { 2-week } \\
\text { intervals or } \\
\text { placebo; } 42 \\
\text { days after } \\
\text { baseline: new } \\
\text { OGTT }\end{array}$ & & \\
\hline $\begin{array}{c}\text { Jorde, } 2009 \\
\text { [46], } \\
\text { Norway }\end{array}$ & $\mathrm{M} / \mathrm{F}$ & $21-75$ & $\begin{array}{l}36 \text { T2DM } \\
\text { patients ( }>1 \\
\text { year with } \\
\text { disease) taking } \\
\text { insulin and } \\
\text { metformin } \\
\text { with stable } \\
\text { HbA1c } \\
\text { (between } \\
7.0-9.5 \% \text { ); } \\
100 \% \text { white } \\
\text { (not reported); } \\
\text { BMI: } \\
32.8 \mathrm{~kg} / \mathrm{m}^{2}\end{array}$ & $\begin{array}{l}24 \mathrm{ng} / \mathrm{mL} ; \mathrm{Ca}: \\
\text { no data }\end{array}$ & $\begin{array}{l}47.3 \mathrm{ng} / \mathrm{mL} \\
\text { (mean delta of } \\
23.3 \mathrm{ng} / \mathrm{mL} \text { ); } \\
\text { Roche Elecsys } \\
\text { D3 }\end{array}$ & $\begin{array}{l}\text { Blood } \\
\text { sampling at } \\
\text { baseline, then } \\
40,000 \mathrm{IU} / \text { week } \\
\text { of D3 or } \\
\text { placebo for } \\
6 \text { months }\end{array}$ & $\begin{array}{l}\text { No changes in } \\
\text { HbAlc; no } \\
\text { improvement in } \\
\text { parameters of } \\
\text { insulin secretion } \\
\text { or resistance; no } \\
\text { change in blood } \\
\text { pressure }\end{array}$ & $\begin{array}{l}\text { Limited number of } \\
\text { patients ( } 70 \% \text { chance } \\
\text { of finding a } 0.5 \% \\
\text { significant difference } \\
\text { in HbA1c); raised } \\
\text { basal vitamin D levels } \\
\text { (? due to Norwegian } \\
\text { habit of taking cod } \\
\text { liver oil; no washout } \\
\text { prior to trial); } 1 \text { case } \\
\text { of hypercalcaemia }\end{array}$ \\
\hline $\begin{array}{l}\text { Witham, } 2010 \\
\text { [44], } \\
\text { Scotland }\end{array}$ & $\mathrm{M} / \mathrm{F}$ & $\begin{array}{l}>18(\text { mean } \\
\text { between } 63.3 \\
\text { and } 66.7)\end{array}$ & $\begin{array}{l}58 \mathrm{~T} 2 \mathrm{DM} \\
\text { patients with } \\
\text { baseline } \\
25 \mathrm{OHD} \text { lev- } \\
\text { els }<40 \mathrm{ng} / \mathrm{mL} \\
\text { and baseline } \\
\text { mean systolic } \\
\text { blood pressure } \\
\text { above target } \\
\text { range for } \\
\text { T2DM; BMI: } \\
\text { around } \\
30 \mathrm{~kg} / \mathrm{m}^{2}\end{array}$ & $\begin{array}{l}16-19 \mathrm{ng} / \mathrm{mL} ; \\
\mathrm{Ca}: \\
12.4-16 \mathrm{mmol} / \mathrm{da}\end{array}$ & $\begin{array}{l}25.2 \mathrm{ng} / \mathrm{mL} \text { in } \\
\text { group } \\
\text { yreceiving } \\
100,000 \mathrm{IU} \text {, } \\
31.6 \mathrm{ng} / \mathrm{mL} \text { in } \\
\text { group } \\
\text { receiving } \\
200,000 \mathrm{IU} ; \\
\text { IDS ELISA }\end{array}$ & $\begin{array}{l}\text { Blood } \\
\text { sampling at } \\
\text { baseline, then } \\
\text { three groups: } \\
\text { placebo; } \\
\text { 100,000 IU of } \\
\text { D3; and } \\
\text { 200,000 IU of } \\
\text { D3; } \\
\text { endothelial } \\
\text { function by } \\
\text { measuring } \\
\text { flow-mediated } \\
\text { dilatation of } \\
\text { brachial artery } \\
\text { at } 8 \text { and } 16 \\
\text { weeks as week } \\
\text { as blood } \\
\text { pressure }\end{array}$ & $\begin{array}{l}\text { No change in } \\
\text { endothelial } \\
\text { function; dystolic } \\
\text { (but not diastolic) } \\
\text { blood pressure fell } \\
\text { significantly } \\
\text { between baseline } \\
\text { and } 8 \text { weeks in } \\
\text { both treated } \\
\text { groups vs placebo; } \\
\text { B-type natriuretic } \\
\text { peptide levels fell } \\
\text { significantly in } \\
\text { 200,000 IU group } \\
\text { vs placebo; no } \\
\text { change in renin or } \\
\text { aldosterone }\end{array}$ & $\begin{array}{l}\text { No confirmation of } \\
\text { results seen in [43] in } \\
\text { similar population } \\
\text { (but more patients } \\
\text { here were taking } \\
\text { statins or ACE } \\
\text { inhibitors); benefit of } \\
\text { supplementation on } \\
\text { systolic blood } \\
\text { pressure in these } \\
\text { hypertensives }\end{array}$ \\
\hline
\end{tabular}

25OHD conc: 25-hydroxyvitamin D concentration; BMI: body mass index; CPBA: chloroperbenzoic acid; HPLC: high-performance liquid chromatography; RIA: radioimmunoassay; ELISA: enzyme-linked immunosorbent assay. 
could be selected [39]. However, since that time, seven other studies have been published, and their results are summarized in Table 2.

In the first of these, Pittas et al. [40] showed that $700 \mathrm{IU} /$ day of D3 and $500 \mathrm{mg} /$ day of $\mathrm{Ca}$ citrate vs placebo prevented increases in plasma glucose and insulin resistance in patients with impaired fasting glucose. The treatment had no apparent effect on fasting glucose in non-glucose-impaired subjects, nor was any effect observed on blood glucose or insulin metabolism in non-diabetic subjects when their VTD levels were corrected [41].

In the large-scale Rosiglitazone Evaluated for Cardiac Outcomes and Regulation of Glycaemia in Diabetes (RECORD) trial, no prevention of the development of T2DM was observed with D3 at $800 \mathrm{IU} /$ day alone or in combination with $1000 \mathrm{mg} / \mathrm{day}$ of calcium carbonate $\left(\mathrm{CaCO}_{3}\right)$-doses that proved insufficient to raise $25 \mathrm{OHD}$ levels to greater than $30 \mathrm{ng} / \mathrm{mL}$ [42]. However, the $8 \%$ of diabetic patients in the treated group had no increased need for medication during the course of the study.

Sugden et al. found that, in their initial studies, $100,000 \mathrm{IU}$ of D2 improved endothelial function (assessed by flow-mediated vasodilatation of the brachial artery in response to hyperaemia and sublingual glyceryl trinitrate) in T2DM patients [43]. These results are of interest because endothelial function is a powerful surrogate marker of cardiovascular risk. However, they could not confirm their findings with either 100,000 or $200,000 \mathrm{IU}$ of D3 [44] (generally thought to be more effective than D2 in raising and maintaining serum VTD levels, although this is still a subject of debate).

However, one interesting observation of the latter study was the reduction in systolic blood pressure in the treated groups, a change that was not observed in studies by Nagpal et al. [45] and Jorde and Figenschau [46]. The former dealt with obese, non-diabetic, healthy Indian men and showed postprandial improvement in insulin sensitivity. In the latter study, patients were overtly diabetic and had stable HbA1c levels that did not change after significant D3 supplementation $(40,000 \mathrm{IU} /$ week for 6 months, equivalent to a total of $1,040,000 \mathrm{IU})$. No improvement in parameters of either insulin secretion or insulin resistance [according to the homoeostasis model assessment (HOMA) method] was observed in this Norwegian cohort, which was not the case of the study published by von Hurst et al. [47] of South Asian insulin-resistant non-diabetic women with VTD deficiency who underwent supplementation with $4000 \mathrm{IU} /$ day of D3 for 6 months (total: $730,000 \mathrm{IU})$. The mean VTD level for this cohort was $32 \mathrm{ng} / \mathrm{mL}$ and, when serum values reached this threshold, an improvement in insulin resistance was observed.

\section{Conclusion}

At present, there is no doubt that a relationship between insufficient VTD and Ca status and T2DM exists. However, the number of interventional studies, and particularly of randomized controlled trials vs placebo, is limited. Moreover, the results observed in some of these studies have been contradictory (although no study has shown worsening of the pathology).
Nevertheless, although it may be that VTD supplementation does not prevent the emergence of diabetes in the healthy population, the potential benefits of its significant supplementation on the various parameters associated with the disease, such as hypertension, are important. VTD supplementation may also have different positive consequences, such as improvement in muscle performance that could lead to increased physical activity and weight loss and, thus, reduced insulin resistance.

Another observation worth noting from the various interventional studies is the method of administration and dosages used. Indeed, for better compliance, large yearly or monthly doses may be more advantageous, but may also have negative outcomes. Indeed, when Taylor and Wise [48] treated three T2DM patients with one intramuscular dose of 300,000 IU of D3, they saw an increase in insulin resistance. Jorde and Figenschau [46] found no significant improvements in the parameters they were studying (which was unexpected, given the results obtained in other interventional studies) but, instead, saw a hypercalcaemic event in one subject. It should also be borne in mind that the protocol followed in that study was intensive $(40,000 \mathrm{IU} /$ week for 6 months). Although it is generally agreed that native VTD is not toxic at the doses used in clinical practice (there is a factor of 1000 between therapeutic and toxic doses), a U-shape curve may still be seen, as was recently reported by Sanders et al. [49] who, on supplementing older women with yearly high doses $(500,000 \mathrm{IU})$ of vitamin D3, unexpectedly found a greater risk of falls.

Furthermore, it should be remembered that all these studies were performed for only a short period of time compared with a lifetime of treatment for chronic diseases such as T2DM. Indeed, it is not reasonable to extrapolate the conclusions of a 6-week trial to the rest of a patient's life.

The medical community is still awaiting more evidence, particularly regarding the prevention of T2DM and improvement of the disease with significant VTD supplementation. Nevertheless, so far, the evidence is sufficient to suggest that T2DM patients should aim to maintain VTD levels greater than $30 \mathrm{ng} / \mathrm{mL}$ over the course of a year.

\section{Conflict of interest statement}

None to declare.

\section{References}

[1] Holick MF. Vitamin D deficiency. N Engl J Med 2007;357:266-81.

[2] Bouillon R, Bischoff-Ferrari H, Willett W. Vitamin D and health: perspectives from mice and man. J Bone Miner Res 2008;23:974-9.

[3] Lappe JM, Travers-Gustafson D, Davies KM, Recker RR, Heaney RP. Vitamin D and calcium supplementation reduces cancer risk: results of a randomized trial. Am J Clin Nutr 2007;85:1586-91.

[4] Visser M, Deeg DJ, Lips P. Low vitamin D and high parathyroid hormone levels as determinants of loss of muscle strength and muscle mass (sarcopenia): the Longitudinal Aging Study Amsterdam. J Clin Endocrinol Metab 2003;88:5766-72.

[5] Munger KL, Levin LI, Hollis BW, Howard NS, Ascherio A. Serum 25-hydroxyvitamin D levels and risk of multiple sclerosis. JAMA 2006;296:2832-8. 
[6] Pfeifer M, Begerow B, Minne HW, Nachtigall D, Hansen C. Effects of a short-term vitamin $\mathrm{D}(3)$ and calcium supplementation on blood pressure and parathyroid hormone levels in elderly women. J Clin Endocrinol Metab 2001;86:1633-7.

[7] Wang TJ, Pencina MJ, Booth SL, Jacques PF, Ingelsson E, Lanier K, et al. Vitamin D deficiency and risk of cardiovascular disease. Circulation 2008;117:503-11.

[8] Zittermann A, Schleithoff SS, Tenderich G, Berthold HK, Korfer R, Stehle P. Low vitamin D status: a contributing factor in the pathogenesis of congestive heart failure? J Am Coll Cardiol 2003;41: $105-12$.

[9] Lemire JM, Ince A, Takashima M. 1,25-Dihydroxyvitamin D3 attenuates the expression of experimental murine lupus of MRL/l mice. Autoimmunity 1992;12:143-8.

[10] Cantorna MT, Hayes CE, Deluca HF. 1,25-Dihydroxycholecalciferol inhibits the progression of arthritis in murine models of human arthritis. J Nutr 1998;128:68-72.

[11] Mathieu C, Waer M, Casteels K, Laureys J, Bouillon R. Prevention of type I diabetes in NOD mice by nonhypercalcemic doses of a new structural analog of 1 25-dihydroxyvitamin D3, KH1060. Endocrinology 1995; 136:866-72.

[12] Urashima M, Segawa T, Okazaki M, Kurihara M, Wada Y, Ida H. Randomized trial of vitamin D supplementation to prevent seasonal influenza A in schoolchildren. Am J Clin Nutr 2010.

[13] Vieth R, Bischoff-Ferrari H, Boucher BJ, Dawson-Hughes B, Garland CF, Heaney RP, et al. The urgent need to recommend an intake of vitamin D that is effective. Am J Clin Nutr 2007;85:649-50.

[14] Souberbielle JC, Body JJ, Lappe JM, Plebani M, Shoenfeld Y, Wang TJ, et al. Vitamin D and musculoskeletal health, cardiovascular disease, autoimmunity and cancer: recommendations for clinical practice. Autoimmun Rev 2010;9:709-15.

[15] Dawson-Hughes B, Heaney RP, Holick MF, Lips P, Meunier PJ, Vieth R. Estimates of optimal vitamin D status. Osteoporos Int 2005;16: 713-6.

[16] Adams JS, Hewison M. Update in vitamin D. J Clin Endocrinol Metab 2010;95:471-8.

[17] Milner RD, Hales CN. The role of calcium and magnesium in insulin secretion from rabbit pancreas studied in vitro. Diabetologia 1967;3: 47-9.

[18] Boucher BJ. Inadequate vitamin D status: does it contribute to the disorders comprising syndrome ' $\mathrm{X}^{\prime}$ ? Br J Nutr 1998;79:315-27.

[19] Mathieu C, Gysemans C, Giulietti A, Bouillon R. Vitamin D and diabetes. Diabetologia 2005;48:1247-57.

[20] Palomer X, Gonzalez-Clemente JM, Blanco-Vaca F, Mauricio D. Role of vitamin $\mathrm{D}$ in the pathogenesis of type 2 diabetes mellitus. Diabetes Obes Metab 2008;10:185-97.

[21] Procopio M, Borretta G. Derangement of glucose metabolism in hyperparathyroidism. J Endocrinol Invest 2003;26:1136-42.

[22] Maestro B, Campion J, Davila N, Calle C. Stimulation by 1,25 dihydroxyvitamin D3 of insulin receptor expression and insulin responsiveness for glucose transport in U-937 human promonocytic cells. Endocr J 2000;47:383-91.

[23] Draznin B, Sussman K, Kao M, Lewis D, Sherman N. The existence of an optimal range of cytosolic free calcium for insulinstimulated glucose transport in rat adipocytes. J Biol Chem 1987;262: 14385-8.

[24] Williams PF, Caterson ID, Cooney GJ, Zilkens RR, Turtle JR. High affinity insulin binding and insulin receptor-effector coupling: modulation by $\mathrm{Ca}^{2+}$. Cell Calcium 1990;11:547-56.

[25] Wright DC, Hucker KA, Holloszy JO, Han DH. $\mathrm{Ca}^{2+}$ and AMPK both mediate stimulation of glucose transport by muscle contractions. Diabetes 2004;53:330-5.

[26] Begum N, Leitner W, Reusch JE, Sussman KE, Draznin B. GLUT-4 phosphorylation and its intrinsic activity. Mechanism of $\mathrm{Ca}(2+)-$ induced inhibition of insulin-stimulated glucose transport. J Biol Chem 1993;268:3352-6.

[27] Lee S, Clark SA, Gill RK, Christakos S. 1,25-Dihydroxyvitamin D3 and pancreatic beta-cell function: vitamin $\mathrm{D}$ receptors, gene expression, and insulin secretion. Endocrinology 1994;134:1602-10.

[28] Bland R, Markovic D, Hills CE, Hughes SV, Chan SL, Squires PE, et al. Expression of 25-hydroxyvitamin D3-1alpha-hydroxylase in pancreatic islets. J Steroid Biochem Mol Biol 2004;89-90:121-5.

[29] Sooy K, Schermerhorn T, Noda M, Surana M, Rhoten WB, Meyer M, et al. Calbindin-D(28k) controls $[\mathrm{Ca}(2+)]$ (i) and insulin release. Evidence obtained from calbindin-d(28k) knockout mice and beta cell lines. J Biol Chem 1999;274:34343-9.

[30] Rabinovitch A, Suarez-Pinzon WL, Sooy K, Strynadka K, Christakos S. Expression of calbindin-D(28k) in a pancreatic islet beta-cell line protects against cytokine-induced apoptosis and necrosis. Endocrinology 2001;142:3649-55.

[31] Ogunkolade BW, Boucher BJ, Prahl JM, Bustin SA, Burrin JM, Noonan K, et al. Vitamin D receptor (VDR) mRNA and VDR protein levels in relation to vitamin $\mathrm{D}$ status, insulin secretory capacity, and VDR genotype in Bangladeshi Asians. Diabetes 2002;51: 2294-300.

[32] Oh JY, Barrett-Connor E. Association between vitamin D receptor polymorphism and type 2 diabetes or metabolic syndrome in community-dwelling older adults: the Rancho Bernardo Study. Metabolism 2002;51:356-9.

[33] Ortlepp JR, Metrikat J, Albrecht M, Von KA, Hanrath P, Hoffmann $R$. The vitamin D receptor gene variant and physical activity predicts fasting glucose levels in healthy young men. Diabet Med 2003;20: $451-4$.

[34] Ishii H, Suzuki H, Baba T, Nakamura K, Watanabe T. Seasonal variation of glycemic control in type 2 diabetic patients. Diabetes Care 2001;24: 1503.

[35] Liang WW. Seasonal changes in preprandial glucose. A1C, and blood pressure in diabetic patients. Diabetes Care 2007;30: 2501-2.

[36] Scragg R, Holdaway I, Singh V, Metcalf P, Baker J, Dryson E. Serum 25-hydroxyvitamin D3 levels decreased in impaired glucose tolerance and diabetes mellitus. Diabetes Res Clin Pract 1995;27: $181-8$.

[37] Scragg R, Sowers M, Bell C. Serum 25-hydroxyvitamin D, diabetes, and ethnicity in the third national health and nutrition examination survey. Diabetes Care 2004;27:2813-8.

[38] Pittas AG, Dawson-Hughes B, Li T, Van Dam RM, Willett WC, Manson $\mathrm{JE}$, et al. Vitamin D and calcium intake in relation to type 2 diabetes in women. Diabetes Care 2006;29:650-6.

[39] Pittas AG, Lau J, Hu FB, Dawson-Hughes B. The role of vitamin D and calcium in type 2 diabetes. A systematic review and meta-analysis. J Clin Endocrinol Metab 2007;92:2017-29.

[40] Pittas AG, Harris SS, Stark PC, Wson-Hughes B. The effects of calcium and vitamin $\mathrm{D}$ supplementation on blood glucose and markers of inflammation in nondiabetic adults. Diabetes Care 2007;30:980-6.

[41] Tai K, Need AG, Horowitz M, Chapman IM. Glucose tolerance and vitamin D: effects of treating vitamin D deficiency. Nutrition 2008;24: 950-6.

[42] Avenell A, Cook JA, MacLennan GS, McPherson GC. Vitamin D supplementation and type 2 diabetes: a substudy of a randomised placebocontrolled trial in older people (RECORD trial ISRCTN 51647438). Age Ageing 2009;38:606-9.

[43] Sugden JA, Davies JI, Witham MD, Morris AD, Struthers AD. Vitamin D improves endothelial function in patients with Type 2 diabetes mellitus and low vitamin D levels. Diabet Med 2008;25:320-5.

[44] Witham MD, Dove FJ, Dryburgh M, Sugden JA, Morris AD, Struthers AD. The effect of different doses of vitamin $\mathrm{D}(3)$ on markers of vascular health in patients with type 2 diabetes: a randomised controlled trial. Diabetologia 2010;53:2112-9.

[45] Nagpal J, Pande JN, Bhartia A. A double-blind, randomized, placebocontrolled trial of the short-term effect of vitamin D3 supplementation on insulin sensitivity in apparently healthy, middle-aged, centrally obese men. Diabet Med 2009;26:19-27.

[46] Jorde R, Figenschau Y. Supplementation with cholecalciferol does not improve glycaemic control in diabetic subjects with normal serum 25hydroxyvitamin D levels. Eur J Nutr 2009;48:349-54. 
[47] Von Hurst PR, Stonehouse W, Coad J, Vitamin D. supplementation reduces insulin resistance in South Asian women living in New Zealand who are insulin resistant and vitamin D deficient - a randomised, placebo-controlled trial. Br J Nutr 2010;103:549-55.

[48] Taylor AV, Wise PH. Vitamin D replacement in Asians with diabetes may increase nsulin resistance. Postgrad Med J 1998;74:365-6.

[49] Sanders KM, Stuart AL, Williamson EJ, Simpson JA, Kotowicz MA, Young $\mathrm{D}$, et al. Annual high-dose oral vitamin D and falls and fractures in olderwomen: a randomized controlled trial. JAMA 2010;303:1815-22 [Erratum in: JAMA 2010;303:2357].
[50] Snijder M, Van Dam RM, Visser M, Deeg D, Seidell J, Lips P. To: Mathieu C, Gysemans C, Giulietti A Bouillon R Vitamin D and diabetes. Diabetologia 2005;48:1247-57 [Diabetologia 2006;49: 217-8].

[51] Wareham NJ, Byrne CD, Carr C, Day NE, Boucher BJ, Hales $\mathrm{CN}$. Glucose intolerance is associated with altered calcium homeostasis: a possible link between increased serum calcium concentration and cardiovascular disease mortality. Metabolism 1997;46: 1171-7. 